\title{
REORIENTASI PENDIDIKAN NASIONAL DALAM MENYIAPKAN DAYA SAING BANGSA
}

\author{
Nanang Nuryanta \\ Dosen Tetap Program Studi Pendidikan Agama Islam \\ Fakultas Ilmu Agama Islam Universitas Islam Indonesia \\ Email: nanangnury@gmail.com \\ DOI: http://dx.doi.org/10.20885/tarbawi.vol8.iss2.art1
}

\begin{abstract}
This article aims at describing the strategy of national education in coping with the challenges of globalization. Globalization has changed the mindset of policy makers in top East Asian countries to reform their education system and governance with desentralization, marketization and internasionalization in order to enhance their education competitiveness. National education needs change in order to adapt with global and international challenges. Policy makers in Indonesia have to reform the education system and governance in terms of regulation, provision, and financing. There are three steps to overcome the problems of national education: (1) reviewing and reforming the old legal framework of national education; (2) improving the processes of education which improve the teaching and learning skills of teachers and developing fun, active and collaborative learning, and (3) building the citizenship culture and developing the learning awareness of communities.
\end{abstract}

Keywords: national education, state competitiveness, education system and governance

\begin{abstract}
Abstrak
Artikel ini mencoa menjelaskan strategi pendidikan nasional dalam menghadapi tantangan-tantangan globalisasi. Globalisasi telah mengubah mindset para pengambil kebijakan di negara-negara maju di kawasan Asia Timur untuk merubah sistem and tata kelola pendidikan mereka melalui desentralisasi, marketisasi dan internasionalisasi untuk meningkatkan daya saing pendidikan mereka. Para pembuat kebijakan
\end{abstract}


di Indonesia harus mereformasi sistem dan tata kelola pendidikan dalam hal regulasi, aturan dan pembiayaan. Ada tiga langkah yang harus diambil untuk mengatasi problem pendidikan nasional: (1) meninjau kembali dan memperbaharui kerangka legal pendidikan nasional yang lama; (2) meningkatkan proses pendidikan yang mampu memperkuat keterampilan mengajar dan pembelajaran para pendidik, dan (3) membangun budaya kewargaan dan mengembangkan kesadaran belajar masyarakat.

Kata Kunci: pendidikan nasional, daya saing negara, sistem dan tata kelola pendidikan

\section{Dasar Pemikiran}

Salah satu topik yang menarik dan tidak pernah usang adalah pembicaraan mengenai pendidikan. Pendidikan ada seiring dengan adanya penciptaan manusia. Pendidikan bukan hanya memiliki dasar filosofis dan menjadi obyek kajian ilmu tetapi juga memiliki nilai praksis yang sangat penting bagi upaya regenerasi umat manusia. Pendidikan merupakan wahana untuk melahirkan generasi penerus dan menjadi kunci bagi kelangsungan suatu bangsa. Pendidikan telah diakui sebagai medium penting bagi suatu negara dalam membentuk karakter bangsa sekaligus mencirikan kualitas bangsa tersebut.

Berdasarkan pengalaman negara-negara maju seperti Amerika Serikat, Inggris, Belgia, Jerman dan Finlandia, untuk memajukan negara, diperlukan reformasi melalui bidang pendidikan. Demikian halnya yang dilakukan oleh negara-negara Asia Timur, seperti Hong Kong, China, Singapura, Taiwan, Korea Selatan, dan Jepang. Negara-negara tersebut melakukan kebijakan penting dalam rangka menghadapi tantangan sekaligus peluang yang dihadirkan oleh globalisasi dengan memperkuat daya saingnya secara internal dan eksternal, yaitu mereformasi sistem pendidikan dan mengubah pengelolaan pendidikan (Mok, dkk., 2005).

Negara-negara Asia Timur memanfaatkan isu-isu krisis keuangan dunia pada tahun 1997 atau 1998 dan tantangan globalisasi yang ditopang oleh pertumbuhan sektor ekonomi, sosial, politik dan didukung oleh perkembangan teknologi informasi untuk bangkit dari keterpurukan. Buktinya saat ini sudah dapat disaksikan bahwa negara-negara tersebut masuk dalam jajaran negara maju dan memiliki tingkat daya saing yang tinggi dalam dunia internasional. Pendidikan telah diyakini sebagai "agent of change". 
Sementara itu dalam konteks keindonesiaan, dapat dikatakan bahwa sejak krisis keuangan yang menimpa Indonesia sampai sekarang, bangsa Indonesia masih berjuang untuk membangun sikap dan mental budaya masyarakat untuk memiliki daya saing. Menurut Ali (2014:1), lahirnya reformasi di Indonesia sejak tahun 1998 telah membangkitkan kembali harapan masyarakat tentang pembangunan nasional untuk menuju bangsa Indonesia yang mandiri, maju, makmur dan berdaya saing tinggi. Mandiri berarti mampu mewujudkan kehidupan sejajar dan sederajat dengan bangsa lain dengan mengandalkan pada kemampuan dan kekuatan sendiri. Maju bermakna tingkat kemakmuran yang juga tinggi disertai dengan sistem dan kelembagaan politik dan hukum yang mantap. Adil berarti tidak ada pembatasan/diskriminasi dalam bentuk apapun, baik antar individu, gender, maupun wilayah. Makmur berarti seluruh kebutuhan hidup masyarakat Indonesia telah terpenuhi sehingga dapat memberikan makna dan arti penting bagi bangsa-bangsa lain (Kementrian PPN/Bappenas, 2014:1)

Dalam Rencana Pembangunan Jangka Panjang (RPJP) khususnya, harapan itu dinyatakan secara eksplisit, terutama karena tertuang dalam visi pembangunan nasional yaitu untuk menjadikan bangsa Indonesia yang mandiri, maju, adil dan makmur. Orientasi pembangunan nasional tersebut termasuk di dalamnya adalah pembangunan sektor pendidikan. Pendidikan nasional memiliki tanggung jawab yang berat karena harus menyiapkan sumber daya manusia yang mampu berdaya saing tinggi.

Pendidikan nasional yang berdasarkan Pancasila dan Undangundang Dasar 1945, berakar pada nilai-nilai agama, kebudayaan nasional Indonesia dan tanggap terhadap tuntutan perubahan zaman terbukti belum mampu menghasilkan sumber daya manusia Indonesia yang kompetitif, kreatif, inovatif dalam percaturan dunia internasional.

Ada persoalan mendasar pada pendidikan nasional Indonesia. Secara konseptual, teoritik dan regulatif, UU No. 20/2003 tentang Sistem Pendidikan Nasional telah menjelaskan orientasi pendidikan ke depan, namun pada kenyataannya belum mampu diwujudkan secara baik. Beberapa arah, strategi dan kebijakan pendidikan nasional dirumuskan secara jelas, namun hasilnya juga belum memuaskan. Situasi demikian menimbulkan problem yang dirumuskan dalam bentuk pertanyaan sebagai berikut: 1) Apakah sistem pendidikan nasional Indonesia sudah usang dan perlu ditinjau kembali?; 2) Proses pendidikan yang bagaimanakah 
yang mampu menjawab permasalahan pendidikan nasional?; dan 3) Faktor apa sajakah yang mempengaruhi kegagalan proses pendidikan nasional di Indonesia?

\section{Tinjauan Teoritik}

Secara teoritik, konsep pendidikan dapat dilihat dari berbagai sumber. Menurut Undang-Undang No. 20 Tahun 2003, pendidikan adalah usaha sadar dan terencana untuk mewujudkan suasana belajar dan proses pembelajaran agar peserta didik secara aktif mengembangkan potensi dirinya untuk memiliki kekuatan spiritual keagamaan, pengendalian diri, kepribadian, kecerdasan, akhlak mulia, serta ketrampilan yang diperlukan dirinya, masyarakat, bangsa dan negara.

Menurut Kunjana (2012) dalam Ika (2014), pendidikan Indonesia perlu dikembalikan pada filosofi pendidikan Ki Hajar Dewantara. Pendidikan yang dimaksud adalah nasionalistik, naturalistik dan spiritualistik yang intinya bahwa pendidikan itu memanusiakan manusia. Bahkan Hardono (2014) menjelaskan ketika mencari beberapa referensi tentang Ki Hajar Dewantara, ada satu artikel menarik yang menyinggung tentang komparasi antara konsep pendidikan Ki Hajar Dewantara dan konsep "Barat". Konsep beliau itu mengedepankan tiga faktor, yaitu "ngerti" (cognitive domain), "ngrasa" (affective domain), dan "nglakoni" (psychomotor domain) http://edukasi. kompas.com/read/2014/05/05/1134472/Kita.Melupakan.Ki.Hajar. Dewantara.dalam.Konsep.Pendidikan.Modern/17/9/2014.

Kedua rumusan tentang konsep pendidikan tersebut sebenarnya sangat holistik karena telah memadukan unsur kognitif, afektif dan psikomotorik, suatu ranah yang lazim dikembangkan dalam dunia pendidikan melalui proses pembelajaran dan pengajaran. Namun demikian, konsep yang bagus tersebut memerlukan pemahaman secara filosofis dan praksis dari semua unsur pendidikan, baik pengambil kebijakan (pemerintah), pendidik, peserta didik, orang tua, masyarakat termasuk pengguna dan penyedia jasa pendidikan.

\section{Tinjauan Empirik}

Secara empirik, khususnya dari sisi praksis pendidikan, implementasi 
pendidikan nasional belum sesuai dengan ruhnya bila ditinjau dari sisi filosofis maupun praksis. Kartadinata (2011) mempertanyakan apakah praktek penyelenggaraan pendidikan selama ini sudah berlandaskan kepada mindset utuh ilmu pendidikan dan konsisten dengan makna yang terkandung di dalam jiwa amanat UU, dalam upaya membawa manusia Indonesia menjadi manusia yang berwatak, bermartabat, dan cerdas sesuai dengan jiwa amanat yang digariskan di dalam UU No. 20/2003.

Fenomena yang tampak menunjukkan banyak terdapat kesenjangan antara mindset utuh pendidikan yang terkandung dalam UU No. 20/2003 dengan mindset pendidikan dalam praktek penyelenggaraan pendidikan, yang menumbuhkan kultur pendidikan tidak sehat. Jika pendidikan bertanggung jawab untuk membangun martabat bangsa yang diwujudkan dalam ketahanan hidup bangsa maka perlu ada upaya penyehatan kultur pendidikan untuk memperbaiki kesenjangan yang disebutkan. Diperlukan reformasi pemikiran, kebijakan, dan praktek penyelenggaraan pendidikan yang tidak semata-mata didasarkan atas pemahaman UU secara tekstual melainkan secara kontekstual dan dilandasi dengan pemaknaan filosofispedagogis yang berbasis nilai-nilai kultur dan agama.

Kunci utama penyehatan pendidikan terletak pada reformasi mindset atau tata pikir secara utuh dalam memaknai hakekat dan praktek penyelenggaraan pendidikan, dan menempatkan ilmu pendidikan sebagai framework dan landasan kerja bagi penyelenggaraan pendidikan untuk memfasilitasi perkembangan peserta didik melalui penciptaan suasana dan proses pembelajaran yang mendidik. Kondisi ini merupakan rongga bagi kebangkitan ilmu pendidikan dalam upaya menegaskan benang merah pendidikan mulai dari filosofi sampai kepada evaluasi yang akan harus berimplikasi kepada penguatan pendidikan guru dan penyehatan penyelenggaraan pendidikan melalui pelurusan mindset pendidikan, regulasi, praktek, dan manajemen pendidikan, agar sejalan dengan esensi pendidikan sebagaimana terkandung dalam jiwa UU No. 20/2003.

Dengan demikian jelaslah bahwa secara empirik praktek pendidikan masih belum mampu menjawab permasalahan pendidikan nasional, karena pembelajaran belum menyentuh aspek filosofis dan praktis. Siapa yang harus bertanggung jawab terhadap masalah ini? Untuk menjawab pertanyaan tersebut kita tidak dapat menyalahkan pihak pendidik saja, akan tetapi semua pihak, baik pemerintah, orang tua, peserta didik, 
pengguna dan penyedia jasa pendidikan harus bertanggung jawab secara bersama-sama.

\section{Deskripsi Hasil Kajian dan Pembahasan}

\section{Hasil Kajian}

Belajar apa yang dilakukan oleh Amerika Serikat, upaya yang perlu dilakukan oleh pemerintah adalah memberikan landasan yang kuat bagi arti pentingnya pendidikan. Dalam buku yang berjudul "Foundation Education" Ornstein dkk (2011) menjelaskan bahwa perubahan harus dimulai dengan memperbaiki profesi guru dengan alasan bahwa guru yang professional akan menghasilkan proses pembelajaran yang berkualitas sehingga menghasilkan peserta didik yang berkualitas pula.

Selanjutnya reformasi sistem pendidikan perlu dilakukan secara baik. Dalam bukunya "Education Reform and Education Policy in East Asia", Ka Ho Mok (2006) menjelaskan bahwa salah satu kebijakan penting dalam rangka menyiapkan sumber daya manusia di negara-negara Asia Timur agar mampu bersaing dalam globalisasi adalah dengan mereformasi sistem pendidikan dan melakukan perubahan pengelolaan pendidikan melalui penetapan kebijakan yang diwujudkan dalam bentuk regulasi, provisi dan pendanaan pendidikan. Sebagai contoh konkrit, apa yang dilakukan oleh Singapura dalam menyiapkan sumber daya manusia yang berkualitas adalah melakukan perubahan kultur akademik masyarakatnya. Sebagaimana dinyatakan oleh PM Goh Chok Tong sebagai berikut:

In order to compete with global advanced economies such as Japan, the United Kingdom, and the United States, in June 1997, the Prime Minister Goh Chok Tong announced Thinking Schools, Learning Nation, a blueprint for reforming the education system in Singapore. The concept of "thinking schools" entails education institutions developing future citizens who will be capable of engaging in critical and creative thinking. The concept of "learning nation" emphasizes that education is a continuum starting with the early childhood years and continuing throughout one's life. Education reforms require a change in mindset among Singaporeans to bring about a spirit of innovation, learning by doing, and self-improvement in order to achieve the ambition of national excellence (Goh 1997). Realizing that future economic competitiveness depends very much upon creativity and innovation, the Singapore government is attempting to change people's mindsets through the reform 
of its education system. Therefore, various government initiatives have been developed to promote independent thinking skills and creative expression in recent years (Fitz Patrick 2003) dalam Mok (2006:138).

Dengan mengambil contoh dari pemerintah Singapura, pendidikan benar-benar dijadikan alat efektif untuk merubah mindset dan kultur masyarakat melalui konsep sekolah berfikir dan bangsa pembelajar. Selain itu, upaya lain yang perlu dilakukan dalam menguatkan pemahaman tentang arti pendidikan, khususnya pengajaran dan pembelajaran pada pendidikan tinggi sebagai lembaga yang paling bertanggung jawab menghasilkan peserta didik sesuai disiplin keilmuan adalah menanamkan pemahaman yang benar tentang disiplin keilmuan untuk menjamin profesionalisme. Hal ini dilakukan untuk menghindari "malpraktik" pendidikan. Hal ini dijelaskan dalam buku yang berjudul " $A$ Handbook for Teaching and Learning in Higher Education: Enhancing Academic Practice" karya Fry dkk (2009).

Sementara itu, untuk dapat memberikan acuan bagaimana cara untuk dapat menghasilkan pemimpin lembaga pendidikan maka salah satu buku yang dapat dijadikan pegangan adalah "Preparing Principals for a Changing World: Lesson from Effective School Leadership Programs" karya Hammond dkk (2010). Buku ini menjelaskan langkah-langkah dalam menyiapkan kepala sekolah yang komunikatif, kreatif, inovatif dan visioner sehingga mampu melakukan perubahan pada institusi pendidikan.

\section{Pembahasan}

Setelah mencermati beberapa pengalaman negara-negara maju dalam melakukan upaya melakukan reformasi pendidikan dan pengelolaan sistem pendidikan maka menurut penulis sudah selayaknya apabila bangsa Indonesia melalui pemerintah meninjau kembali sistem pendidikan nasional. Peninjauan ini bukan berarti harus merubah total sistem pendidikan nasional, tetapi meninjau kembali beberapa konsep yang kurang relevan dengan tuntutan perubahan global, khususnya yang terkait substansi pendidikan dan model pengelolaannya. Penguatan kembali "core pendidikan" sesuai kultur bangsa Indonesia nampaknya perlu mendapatkan prioritas. Menurut Nuryanta (2014), beberapa nilai inti (core values) pendidikan nasional adalah nilai keagamaan, keadilan, kebebasan, persamaan, cinta tanah air, kesesuaian, kemerdekaan, kebudayaan, kemanusiaan, kekeluargaan, gotong royong, 
keramahtamahan, kedisiplinan, menghargai perbedaan, negara maritim dan kewarganegaraan yang harus ditumbuhkan sejak awal pendidikan, khususnya mulai dari pendidikan pra-sekolah.

Konsep Negara Maritim yang diprioritaskan oleh Presiden Joko Widodo perlu mendapat perhatian serius. Kalau pada konsep sebelumnya "laut" adalah "pemisah" antar pulau, maka sekarang konsep tersebut telah berubah menjadi "pemersatu" antar pulau. Konsep ini memerlukan perubahan mindset seluruh warga negara. Masyarakat harus dipahamkan bahwa laut bukanlah halangan akan tetapi menjadi wahana transportasi untuk negara maritim, terutama beberapa tahun ke depan yang sangat mungkin menggantikan transportasi darat. Perubahan mindset ini harus mulai disebarluaskan kepada masyarakat melalui pendidikan. Konsekuensi logisnya adalah masyarakat Indonesia tidak boleh lagi takut "laut". Maka pembelajaran renang perlu dimasukkan ke dalam kurikulum, bahkan perlu diwajibkan. Hal ini sejalan dengan ajaran Rasulullah SAW, bahwa renang adalah salah satu materi pelajaran yang wajib diberikan kepada peserta didik, sebagaimana sabda Beliau: "ajarilah anak-anakmu memanah, berkuda dan berenang" (HR. Ath-Thawawi).

Sementara itu, konsep sekolah pemikiran (thinking school) yang dikembangkan oleh pemerintah Singapura dalam menghasilkan peserta didik yang kritis, kreatif dan inovatif perlu digalakkan dalam pendidikan di Indonesia. Kalau di Indonesia ada LEMHANAS yang dijadikan sebagai pendidikan yang strategis dan mendidik kalangan elit politik minoritas (legislatif, eksekutif, pimpinan perguruan tinggi, militer) maka model ini dapat diadopsi tetapi pesertanya harus diperluas. Pola pendidikan di LEMHANAS harus dibangun untuk generasi muda yang potensial sehingga menjaring banyak peserta didik potensial yang diperlukan dalam mendukung proses pembangunan bangsa. Alasan ini untuk mengatasi kenyataan bahwa berdasarkan laporan Kementrian Pembangunan Nasional/Badan Perencanaan Pembangunan Nasional tahun 2014, masih terdapat 2,1\% anak usia 7-12 tahun dan 10,5\% anak usia 13-15 tahun yang tidak sekolah pada tahun 2012. Sebagian besar anak usia 13-15 tahun yang tidak sekolah adalah lulusan SD/MI yang tidak melanjutkan ke jenjang SMP/MTs (Kementrian PPN/Bappenas, 2014: 6).

Oleh karena itu, ada 10 (sepuluh) isu strategis yang diangkat untuk mengatasi permasalahan pendidikan berdasarkan Rencana Pembangunan 
Jangka Menengah Nasional 2015-2019 sub-bidang pendidikan. Kesepuluh isu strategis adalah sebagai berikut:

a. Pelaksanaan program Indonesia pintar melalui wajib belajar 12 tahun

b. Peningkatan kualitas pembelajaran

c. Peningkatan manajemen guru, pendidikan keguruan, dan reformasi LPTK

d. Peningkatan akses, kualitas, relevansi dan daya saing pendidikan tinggi

e. Peningkatan pendidikan dan pengembangan anak usia dini

f. Peningkatan ketrampilan kerja dan penguatan pendidikan orang dewasa

g. Peningkatan pendidikan agama, pendidikan kewargaan dan pendidikan karakter untuk mendukung revolusi mental

h. Peningkatan efisiensi pembiayaan pendidikan

i. Peningkatan tata kelola pendidikan (Kementerian PPN/Bappenas, 2014:4).

Kesepuluh isu strategis tersebut sangat penting untuk dipahami oleh semua pihak, khususnya para pendidik untuk mendapatkan penguatan dari sisi filosofis, epistimologis dan aksiologis sehingga memudahkan dalam implementasi praksisnya. Konsep ini perlu mendapatkan penguatan dalam proses pembelajaran sehingga pemahaman filosofis dan praksis dapat diperoleh dalam penelaahan peserta didik. Bahkan secara lebih tegas Abin Syamsuddin Makmun (2014:17) menyebutkan bahwa kemungkinan model lain dalam ranah telaahan bidang pendidikan itu, ialah berdasarkan pertimbangan kepentingan pengembangan 'body of knowledge' dan pengayaan khazanah ilmiah disiplin ilmu pendidikan itu sendiri, seperti yang banyak diminati oleh masyarakat akademik di perguruan tinggi. Dalam hal ini, Abin menawarkan suatu model diagramatik-sirkularyang menunjukkan posisi dan interelasi antara bidang disiplin kajian keilmuan sesuai dengan struktur organisasi kelembagaan disiplin ilmu kependidikan yang secara faktual eksis hingga saat ini. Lebih lanjut Abin menjelaskan bahwa ditinjau dari segi substansi bidang telaahannya dapat dikategorikan ke dalam tiga lapisan (layers), yaitu Disiplin Ilmu Pendidikan (FIP/JIP) sebagai intinya (core, central, nucleus) pada lapisan pertama (A), kemudian bidang-bidang Pendidikan Disiplin Ilmu pada layer kedua (B.1-dst), serta bidang-bidang Disiplin Ilmu lain 
pada lapisan ketiga (C.1-dst). Ketiga lapisan gugus bidang keilmuan itu ternyata memperlihatkan adanya semacam "sharing" secara substansial, A dengan $\mathrm{B}, \mathrm{B}$ dengan $\mathrm{A}$ dan $\mathrm{C}$ serta $\mathrm{C}$ dengan $\mathrm{B}$.

Dengan adanya strategi penelaahan yang benar, diharapkan sebuah perencanaan, regulasi dan kebijakan yang dikeluarkan pemerintah akan memperoleh penguatan keilmuan sehingga memiliki nilai filosofis akademis bukan hanya tekstual normatif saja. Proses pendidikan harus memberikan ruang yang lebih bagi terselenggaranya pelaksanaan pengajaran dan pembelajaran yang lebih interaktif, humanis, demokratis, dialogis, dan analitis-kritis sehingga kajian pendidikan mengenai pada sasaran yang diinginkan. Metode pembelajaran pada pendidikan tinggi diharapkan lebih berorientasi pada observation-based (discovery) learning dan collaborative learning dan mempertimbangkan aspek neurologi dan psikologi (Paparan Mendikbud dalam Sosialisasi Kurikulum 2013 pada tangga16 Maret 2013).

Sementara itu PAIKEM GEMBROT (Pembelajaran Aktif, Inovatif, Kreatif, Efektif dan Menyenangkan, Gembira dan Berbobot) dipilih untuk mengembangkan pendidikan pra-sekolah samapai pendidikan dasar. Karena PAIKEM GEMPBROT memiliki 3 (tiga) landasan yaitu: landasan filosofis, psikologi dan yuridis (Khoiru Ahmadi dan Sofaan Amri, 2011 dalam Binti Nurjannah, 2014, diposkan oleh Binti Nurjannah dalam http://bintinurjannah.blogspot.com/2013/12/ model-paikem-gembrot.html/diakses:13/11/2014).

\section{Landasan Filosofis}

Secara filosofis pendidikan kontruktivisme dan humanisme menekankan bahwa peserta didik mempunyai kemampuan untuk melakukan perubahan secara signifikan dalam kehidupannya walaupun bersifat evolusionis, karena lingkungan hidup peserta didik merupakan suatu dunia yang terus berproses secara evolusionis pula.

Pengetahuan peserta didik adalah kumpulan kesan-kesan dan informasi yang terhimpun dalam pengalaman empirik yang partikular dan seharusnya siap untuk digunakan. Kesan-kesan dari luar itu diterima oleh indera, dimana indera jasmani merupakan satu kesatuan dengan rohani. Oleh karena itu, jasmani dan rohani perlu mendapatkan 
kebebasan dalam menerima kesan-kesan dari lingkungannya dan dalam memanifestasikan kehendak serta tingkah lakunya. Dengan demikian pendidikan yang menyeluruh dan menyentuh aspek jasmani dan rohani dengan memberikan tempat yang wajar pada peserta didik.

\section{Landasan Psikologi}

Pemahaman peserta didik, berkaitan dengan aspek kejiwaan individu, merupakan salah satu kunci keberhasilan pendidikan. Oleh karena itu psikologi perkembangan sangat diperlukan terutama dalam menentukan isi/materi yang diberikan kepada peserta didik agar tingkat keluasan dan kedalamannya (isi/materi) sesuai dengan tahap perkembangan peserta didik. Sedangkan psikologi belajar memberikan kontribusi dalam hal bagaimana isi/materi disampaikan kepada anak didik dan bagaimana pula anak didik harus mempelajarinya.

PAIKEM GEMBROT didorong untuk mendapatkan pengetahuan langsung dari pengalaman yang hanya bisa diperoleh dari lingkungan peserta didik. Dalam interaksi anak didik dengan lingkungan sosial maupun material, peserta didik sangat mungkin memperoleh penemuan. Jadi, pembelajaran ini lebih memfokuskan pada kesuksesan peserta didik dalam mengorganisasikan pengalaman mereka, bukan sekedar refleksi atas berbagai informasi dan gejala yang diamati. Peserta didik lebih diutamakan untuk mengkontruksi sendiri pengetahuannya melalui asimilasi dan akomodasi.

\section{Landasan Yuridis}

PAIKEM GEMBROT berkaitan dengan berbagai kebijakan atau peraturan yang mendukung pelaksanaan PAIKEM GEMBROT di sekolah. Landasan yuridis tersebut adalah: a) Undang-Undang Dasar Republik Indonesia tahun 1945, pasal 31 menyatakan bahwa "Setiap warga Negara berhak mendapatkan pendidikan yang layak". b) UU No. 23 Tahun 2002 tentang Perlindungan Anak pasal 9, menyatakan bahwa "Setiap anak berhak memperoleh pendidikan dan pembelajaran dalam rangka pengembangan pribadinya dan tingkat kecerdasannya sesuai dengan minat dan bakatnya". c) UU No. 20 Tahun 2003 Sistem Pendidikan Nasional pada Bab I Ketentuan umum pasal 1 tentang definisi pendidikan menekankan kepada mewujudkan suasana belajar dan proses pembelajaran dan keterlibatan peserta didik 
secara aktif mengembangkan potensi dirinya". Sedangkan pada Bab V pasal 1-b menyatakan bahwa "Setiap peserta didik pada setiap satuan pendidikan berhak mendapatkan pelayanan pendidikan sesuai bakat, minat dan kemampuannya"

Adapun faktor-faktor yang dapat mempengaruhi kegagalan pendidikan nasional antara lain:

a. Belum meratanya kesempatan memperoleh pendidikan dan kurangnya akses pendidikan. Pendidikan adalah hak segala warga Negara tanpa memandang status sosial, agama, etnis dan ras. Namun pada kenyataannya masih banyak warga Negara Indonesia yang belum memperoleh kesempatan pendidikan. Kesenjangan APS penduduk usia 13-15 tahun antar kabupaten/kota masih lebar, yaitu antara 13,1 persen (Pegunungan Bintang, Papua) sampai dengan 100 persen (Kota Yogyakarta dan Kota Kediri) lihat sumber (Kemenerian PPN/Bappenas, 2014:8). Demikian pula akses pendidikan masih terdaat 2,1\% anak usia 7-12 tahun dan 10,5\% anak usia 13-15 tahun yang tidak sekolah pada tahun 2012. Sebagian besar anak usia 13-15 tahun yang tidak sekolah adalah lulusan SD/MI yang tidak melanjutkan ke jenjang SMP/MTs (Kementrian PPN/Bappenas, 2014:6). Kesenjangan partisipasi dan angka melanjutkan ke pendidikan menengah ini lebih banyak disebabkan oleh pendapatan, antar wlayah dan antar jenis kelamin.

b. Kualitas dan relevansi pendidikan. Kualitas dan relevansi pendidikan Indonesia masih dalam kategori rendah. pernyataan ini didasarkan pada persepsi pelaku usaha terhadap layanan karyawan yang berasal dari Bank Dunia, dimana rata-rata skill tenaga kerja Indonesia masih ada di bawah $30 \%$ dengan kategori poor or very poor dan baru $75 \%$ yang mampu memberikan kepuasan dan sesuai harapan pemberi kerja. Fenomena ini sangat wajar, karena pendidikan vokasional di Indonesia kebanyakan belum mempunyai sektor industri sebagai tempat untuk kerja praktek. Coba kita bandingkan dengan United Kingdom, bahwa pendidikan vokasional di Inggris mensyaratkan memiliki industri sebagai lahan praktiknya. Kalaupun sekolah sudah memiliki link dengan industri namun pihak industri belum memberikan jaminan untuk dapat menerima peserta didik agar dapat bekerja di perusahaannya. Kebanyakan SMA/SMK belum 
didukung dengan fasilitas yang memadai.

c. Kurangnya manajemen guru, pendidikan keguruan dan reformasi LPTK. Jumlah dan distribusi guru masih perlu diperbaiki. Surplusnya guru di Pulau Jawa dan kurangnya guru di beberapa propinsi, seperti Kalimantan, Riau Pedalaman, Papua jelas sekali akan mempengaruhi kualitas pendidikan. Demikian pula ketidakseimbangan antara guru tetap dengan guru honorer ataupun guru bantu termasuk pendapatannya merupakan pekerjaan rumah yang menuntut penyelesaian segera. Selain itu, pendidikan keguruan di Indonesia sekarang ini cenderung dijadikan proyek bukan difungsikan sebagaimana seharusnya untuk mendidik guru yang professional. Pendidikan keguruan banyak yang bergeser ke arah pengembangan disiplin keilmuan murni daripada mengembangkan profesi, skill dan keteladanan. Selain itu, beberapa LPTK terakreditasi masih rendah. Kondisi ini membuktikan bahwa rendahnya akreditasi menunjukkan rendahnya kinerja lembaga tersebut. Sementara program sertifikasi memang sudah berhasil meningkatkan kesejahteraan guru tetapi belum mampu meningkatkan kualitas mutu dan hasil pembelajaran peserta didik (Kementerian PPN/Bappenas, 2014:18).

d. Akses, kualitas, relevasi dan daya saing pendidikan tinggi di Indonesia yang relatih rendah. Pendidikan tinggi memiliki posisi strategis dalam penyiapan sumber daya manusia suatu bangsa. Pendidikan tinggi bukan hanya menyiapkan bekal disiplin keilmuan tetapi juga skill dan riset yang dibutuhkan bagi pasar kerja dan menjadi tolok ukur daya saing bangsa. Berdasarkan data Kementerian PPN/Bappenas (2014:20) dari sumber Bank Dunia menggambarkan bahwa akses ke layanan pendidikan tinggi antar kelompok pendapatan dan jenis kelamin belum merata. Tingkat partisipasi kelompok masyarakat kaya sebesar 43,6\% dibandingkan dengan kelompok masyarakat miskin sebesar 4,4\%. Tahun 2013 rasio kesetaraan gender partisipasi PT mengalami kenaikan menjadi 109,6\%, dibandingkan tahun 2011 sebesar 103,5\%. Persentase PTS/PTN yang terakreditasi masih rendah (PTN terakreditasi internasional 30\% - PTS <10\%; PTN terakreditasi nasional 56\% - PTS < 50\%; PTN berstandar local 14\% - PTS 41\% dan belum terakreditasi 0,2\%). Data lain menyebutkan bahwa baru 52,8 
persen dosen berkualifikasi S2 dan 9,5 persen berkualifikasi S3, jumlah karya ilmiah dosen/peneliti yang dipublikasikan pada jurnal internasional dan jumlah sitasi masih rendah, perguruan tinggi belum sepenuhnya dapat menjalankan fungsi IPTEK, relevansi pendidikan tinggi dengan dunia kerja masih rendah, kemitraan perguruan tinggi dengan dunia usaha/dunia industri belum berkembang dan otonomi PT masih rendah.

e. Sulitnya merubah kultur masyarakat Indonesia. Salah satu keberhasilan reformasi pendidikan di China Daratan, Jepang dan empat Macan Asia Timur (Hong Kong, Taiwan, Korea Selatan dan Singapura) adalah mereformasi kultur warganegaranya. Kesadaran masyarakat untuk bangkit dan siap terhadap segala tantangan, disiplin, kerja keras, belajar sepanjang hayat dan kepatuhan terhadap hukum berjalan dengan baik. Budaya Negara-negara Asia Timur tersebut berbanding terbalik dengan Indonesia. Mengubah kultur masyarakat Indonesia merupakan pekerjaan rumah terbesar reformasi di Indonesia. Menurut penulis, Undang-undang, regulasi dan ketentuan-ketentuan hukum di Indonesia sudah baik tetapi belum memiliki dampak perubahan signifikan pada bangsa karena kultur warganegaranya. Learning Nation yang dijadikan blueprint reformasi sistem pendidikan di Singapura terbukti efektif mengubah budaya warganegaranya sehingga menjadi negara yang maju dan kompetitif pada dunia global.

f. Krisis jati diri bangsa. Menurut Kementerian PPN/Bappenas (2014:10) tiga masalah pokok pembangunan dalam rangka mencapai tujuan nasional bangsa Indonesia, yaitu: 1) merosotnya kewibawaan negara, 2) melemahnya sendi-sendi perekonomian nasional, dan 3) merebaknya intoleransi dan krisis kepribadian bangsa. Politik penyeragaman telah mengikis karakter Indonesia sebagai bangsa pejuang, memudarkan solidaritas dan gotong royong serta meminggirkan kebudayaan. Jati diri bangsa terkoyak oleh merbaknya konflik sectarian dan berbagai bentuk intoleransi. Negara mengabaikan penghormatan dan pengelolaan keragaman dan perbedaan yang menjadi karakter Indonesia sebagai bangsa yang majemuk. Sikap untuk tidak bersedia bersama dalam sebuah komunitas yang beragam telah melahirkan ekspresi intoleransi dalam bentuk kebencian, permusuhan, diskriminasi, dan tindakan 
kekerasan terhadap yang "berbeda". Kegagalan pengelolaan keragaman itu terkait dengan masalah ketidakadilan dalam realokasi dan redistribusi sumber daya nasional yang memperuncing kesengajaan sosial. Pada saat yang sama, kemajuan teknologi informasi dan transportasi yang begitu cepat telah melahirkan "dunia tanpa batas" (borderless state) yang pada gilirannya membawa dampak negatif berupa kejut budaya (culture shock) dan ketunggalan identitas global di kalangan generasi muda Indonesia. Hal ini mendorong pencarian kembali basis-basis identitas primordial sebagai representasi simbolik yang menjadi pembeda dengan lainnya. Konsekuensinya, bangsa ini berada di tengah pertarungan antara dua arus kebudayaan. Di satu sisi, manusia Indonesia dihadapkan pada arus kebudayaan yang didorong oleh kekuatan pasar yang menempatkan manusia sebagai komoditas semata. Di sisi lain, muncul arus kebudayaan yang menekankan penguatan identitas primordial di tengah derasnya arus globalisasi. Akumulasi dari kegagalan mengelola dampak persilangan tersebut menjadi ancaman bagi pembangunan karakter bangsa (nation and character building).

\section{Solusi yang ditawarkan untuk mengatasi permasalahan pendidikan nasional}

Menurut penulis ada beberapa solusi yang perlu ditawarkan untuk menjawab permalasahan pendidikan nasional, yaitu:

a. Mereformasi sistem pendidikan nasional dan mengadopsi beberapa strategi yang ditempuh negara-negara maju dan negaranegara Asia Timur. Reformasi sistem pendidikan terutama yang menyangkut pengelolaan pendidikan, mulai pra sekolah sampai pendidikan tinggi. Model pengelolaan desentralisasi, privatisasi dan korporatisasi sangat layak untuk diterapkan pada pendidikan di Indonesia. Strategi internasionalisasi dan benchmarking perlu dikembangkan di pendidikan tinggi dikombinasikan dengan manajemen mutu pendidikan (education quality assurance). Kerjasama dengan perguruan tinggi asing harus diperkuat untuk meningkatkan international acknowledgement. Sementara reformasi pendidikan pra sekolah sampai pendidikan menengah dilakukan dengan melakukan peninjaun kurikulum dan meningkatkan 
keterlibatan pihak swasta, orang tua, masyarakat, dunia industri serta donasi asing dalam pengelolaan pendidikan. Selain itu, pemerintah perlu didorong untuk memfasilitasi model training atau pendidikan khusus untuk menyiapkan kepala sekolah yang berkualitas yang berbasis skill kepemimpinan (principals-based skill leadership) dan pimpinan perguruan tinggi yang expertise sebagai wahana untuk memberi otonomi institusi pendidikan. Kebijakan pengelolaan pendidikan harus diikuti dengan regulasi, provisi dan pendanaan yang jelas dan kemudian diikuti "kepatuhan" semua pihak dalam mengawal penyelenggaran dan pengelolaan pendidikan.

b. Proses pendidikan dimulai dengan upaya memperbaiki kualitas pendidikan guru. dengan asumsi bahwa guru yang berkualitas akan menghasilkan pembelajaran yang bermutu dan akhirnya menghasilkan output yang baik. Pengakuan terhadap profesi guru yang dicanangkan oleh Presiden Susilo Bambang Yudoyono pada tanggal 2 Desember 2004 dan telah melahirkan UU No 14 Tahun 2005 harus menjamin profesionalitas guru atau pendidik bukan hanya dari aspek kesejahteraan finansial tetapi juga mutu pembelajaran dan pengajaran. Metode pembelajaran "PAIKEM GEMBROT" secara konsisten harus dikembangkan dan diaplikasikan untuk pendidikan pra sekolah sampai pendidikan menengah. Sedangkan metode active learning dan collaborative learning digunakan untuk pendidikan tinggi.

c. Solusi terakhir adalah dengan mengatasi masalah-masalah pendidikan nasional dengan mengimplementasikan dan meningkatkan sepuluh strategi pembangunan bidang pendidikan dengan diikuti "komitmen" yang kuat dari semua stakeholder pendidikan, baik internal maupun eksternal.

\section{Simpulan, Implikasi dan Rekomendasi}

\section{Simpulan}

Setelah mencermati, membahas dan menganalisis pendidikan nasional maka penulis menyimpulkan sebagai berikut:

a. Sistem pendidikan nasional yang bersumber pada UU No Tahun 2003 belum mampu menghasilkan sumber daya manusia sesuai dengan tujuannya. Oleh karena itu perlu ditinjau kembali dan 
bahkan direformasi untuk memperkuat daya saing manusia Indonesia.

b. Proses pendidikan diperbaiki dengan perbaikan pendidikan guru atau pendidik yang mampu memahami proses pendidikan dari sisi folosofis, epistimologis maupun praksis. Pengajaran dan pembelajaran ditempuh dengan metode yang dialogis, interaktif dan komunikatif.

c. Reformasi budaya dan menumbuhkembangkan kesadaran belajar warganegara Indonesia adalah solusi terhadap berbagai faktor yang mempengaruhi pendidikan nasional.

\section{Implikasi}

Kebijakan reformasi sistem pendidikan nasional dan penyelenggaraan pendidikan memerlukan penelahaan secara mendalam dan intensif yang melibatkan para pengkaji kebijakan dan peneliti termasuk para praktisi pendidikan di Indonesia. Upaya ini perlu dilakukan dalam rangka mempercepat kemampuan daya saing bangsa dengan tetap berpegang pada kearifan budaya lokal. Untuk itu, kajian kebijakan dan manajemen pendidikan merupakan topik penelitian yang menarik dan harus diintensifkan agar memberikan kontribusi terhadap perubahan pada sistem pendidikan nasional. Pengambilan kebijakan yang tidak didasarkan pada hasil riset telah membuktikan bahwa ada dampak negatif yang sangat besar pada saat ini harus menjadi pelajaran berharga bagi pengambil kebijakan. Implikasi ini perlu dipertimbangkan agar pengambilan kebijakan tepat pada sasaran yaitu membawa kepada kesejahteraan rakyat.

\section{Rekomendasi}

Melalui tulisan singkat ini penulis ingin memberikan rekomendasi kepada:

1. Pengambil kebijakan pendidikan, yaitu pemerintah melalui Kementerian Pendidikan Dasar dan Menengah serta Kementerian Pendidikan Tinggi, Riset dan Tekonologi agar meninjau kembali UU No 20 Tahun 2003 dengan melakukan kajian intensif dan riset kebijakan terkait pendidikan untuk perubahan budaya dan penguatan kualitas sumber daya 


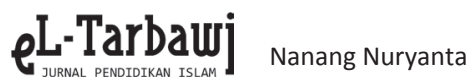

manusia Indonesia.

2. Pemerhati pendidikan, mahasiswa pascasarjana untuk lebih intensif melakukan kajian pendidikan dan riset yang terkait dengan tema manajemen pendidikan nasional.

3. Seluruh warga Negara Indonesia harus berpartisipasi secara aktif dalam gerakan reformasi pendidikan untuk menghasilkan pendidikan yang lebih baik pada masa depan. 


\section{Daftar Pustaka}

Abin Syamsuddin Makmun. 2014. Konsep Pendidikan dan Pembelajaran: Kebutuban Penelitian di Bidang Ilmu Pendidikan. Bandung: UPI

Ali, Muhammad. 2014. Pendidikan Untuk Pembangunan Nasional: Menuju Bangsa Indonesia yang Mandiri dan Berdaya Saing Tinggi. Edisi Kedua. Bandung: PT. Imperial Bhakti Utama

Fry, Heater, Ketteridge, Steve, Marshall, Stephanie. 2009. A Handbook For Teaching and Learning in Higher Education: Enhancing Academic Practice. New York and London: Routledge Taylor \& Francis Group

Hammond, Linda Darling, Meyerson, Debra, LaPointe, Michelle, Orr, Margaret Terry. 2010. Preparing Principals for a Changing World: Lesson from Effective School Leadership Programs. USA: Jossey Bass

Hardono, Indi. 2014. Konsep Pendidikan Ki Hajar Dewantara. http://edukasi.kompas.com/read/2014/05/05/1134472/Kita. Melupakan.Ki.Hajar.Dewantara.dalam.Konsep.Pendidikan. Modern/17/9/2014

Kementrian PPN/Bappenas.2014.RancanganAwalRencanaPembangunan Jangka Menengah Nasional 2015-2019: Buku I Agenda Pembangunan Nasional.Jakarta: Kementrian Perencanaan Pembangunan Nasional/ Bapan Perencanan Pembangunan Nasional.

Kementrian PPN/Bappenas. 2014. Rencana Teknokratik RPJM 20152019 Sub Bidang Pendidikan. Jakarta: Kementrian Perencanaan Pembangunan Nasional/Bapan Perencanan Pembangunan Nasional.

Mok, Ka Ho. 2006. Education Reform and Education Policy in East Asia. New York: Routledge: Taylor \& Francis Group

Nuryanta, Nanang. 2014. Slide Perkuliahan Pendidikan Nasional. Yogyakarta: FIAI UII

Ornstein, Allan C dan Levine, U Daniel. 2008. Foundations of Education. Tenth Edition. USA:Houghton Mifflin Company

Sunaryo Kartadinata. 2011. "Resureksi Ilmu Pendidikan dan Penyehatan Kultur Pendidikan”. Reorganisasi dan Penataan Ulang Pemikiran 


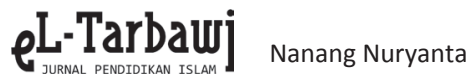

dari Berbagai Tulisan dan Presentasi Tahun 2010-2011. Makalah. Bandung: UPI 